J. Akademika. Kim. 6(4): 214-218, November 2017

ISSN 2302-6030 (p), 2477-5185 (e)

\title{
PENGARUH PENERAPAN MODEL PEMBELAJARAN KOOPERATIF TIPE SCRAMBLE TERHADAP HASIL BELAJAR SISWA PADA MATERI HIDROKARBON DI KELAS X SMA NEGERI 8 PALU
}

\author{
Effect of Application the Cooperative Learning Model Type Scramble on Student's Learning \\ Outcomes in Hydrocarbon Material in Class X SMA Negeri 8 Palu
}

\author{
*Ilham Suliadi, Irwan Said, dan Minarni R. Jura \\ Pendidikan Kimia/FKIP - Universitas Tadulako, Palu - Indonesia 94118 \\ Received 08 September 2017, Revised 09 October 2017, Accepted 08 November 2017
}

\begin{abstract}
This study aimed to obtain description the application the cooperative learning model type scramble on student's learning outcomes in hydrocarbon material in class X SMAN 8 Palu. This type of research was quasiexperimental research. This study was conducted at two group, 27 students in class $X B$ as an experimental group and 28 students in class $X A$ as a control group. The testing of student's learning outcomes data used the statistical analysis $t$-test of the two parties with the prerequisite test: normality test and homogeneity test. The results of the data analysis, it was obtained the average values of students in experiment class $\left(\mathrm{X}_{1}\right)$ was 72.40 with a standard deviation of 11.86 and students in control class $\left(\mathrm{X}_{2}\right)$ was 67 with a standard deviation of 12.03 . Based on the results of testing hypotheses by statistical $t$-test two parties, it was obtained $-t_{\text {table }}<t_{\text {calculation }}>+t_{\text {table }}$ $\left(t_{\text {calculation }}=2.37\right.$ and $\left.t_{\text {table }}=1.67\right)$ with a significance level $\alpha=0.05$ and degrees of freedom 53 , then $H_{0}$ wass rejected and $h_{a}$ wasaccepted. It can be concluded that there is the effect of application the cooperative learning model type scramble toward student's learning outcomes in the hydrocarbon material in class X SMA 8 Palu.
\end{abstract}

Keywords: Cooperative learning model, scramble, hydrocarbons, learning outcomes

\section{Pendahuluan}

Pendidikan merupakan usaha membimbing individu untuk meningkatkan pengetahuan dan mengembangkan potensi yang ada dalam individu tersebut (Gustiana, 2012). Menciptakan manusia yang terampil dan memiliki keahlian bukanlah hal yang mudah. Pencapaian tujuan pembelajaran pendidikan merupakan salah satu keberhasilan dalam kegiatan belajar mengajar. Guru dalam kegiatan belajar mengajar harus berusaha menciptakan kondisi belajar yang efektif, mengembangkan bahan pengajaran dengan baik, dan meningkatkan kemampuan siswa untuk memperoleh pelajaran serta harus memahami dan menguasai tujuan pembelajaran yang hendak dicapai. Tetapi, pada kenyataan saat ini banyak kegiatan belajar mengajar yang tidak mampu mencapai tujuan pembelajaran khususnya pada mata pelajaran kimia (Nasution, 2014).

Pembelajaran kimia pada umumnya siswa harus mempelajari konsep-konsep ilmu kimia maupun materi kimia yang bersifat hitungan matematis. Proses pembelajaran seringkali siswa sulit untuk memahami materi yang diajarkan oleh guru yang berdampak pada siswa menjadi malas belajar sehingga hasil balajar yang diperoleh menjadi tidak maksimal. Oleh karena itu, peranan guru sangatlah penting untuk dapat mendesain proses

*Korespondensi

Ilham Suliadi

Program Studi Pendidikan Kimia, Fakultas Keguruan dan Ilmu Pendidikan, Universitas Tadulako

e-mail: ilhamsuliadi@gmail.com

Published by Universitas Tadulako 2017 pembelajaran yang interaktif, inovatif, dan efektif sehingga dapat meningkatkan motivasi belajar siswa yang dapat berdampak positif pada peningkatan hasil belajar siswa.

Hidrokarbon merupakan materi pembelajaran kimia yang mengharuskan siswa untuk memahami penggolongan hidrokarbon berdasarkan bentuk rantainya (alifatik, alisiklik dan aromatik), jenis ikatan atomnya (jenuh dan tak jenuh), tata namanya berdasarkan aturan IUPAC (International Union of Pure and Applied Chemistry), isomer, serta sifat-sifatnya (Purba, 2006). Materi ini membutuhkan konsentrasi belajar yang kuat untuk dapat memahami konsepkonsep yang ada, ketika siswa kurang memahami konsep maka siswa akan kesulitan untuk menyelesaikan soal-soal yang diberikan. Saat melaksanakan proses belajar mengajar, keaktifan siswa harus selalu diciptakan secara terus menerus dengan menggunakan metode dan strategi mengajar yang tepat. Guru harus dapat menciptakan suasana yang dapat mendorong siswa untuk bertanya, mengamati, serta menemukan konsep yang benar.

Model pembelajaran konvensional guru berdiri di depan kelas mendominasi seluruh kegiatan pembelajaran dan berceramah tentang materi yang sedang dibahas, sedangkan siswa hanya sebagai objek pasif dalam kegiatan pembelajaran tersebut. Keadaan seperti ini menyebabkan siswa kurang memperhatikan penjelasan guru dan terlibat dalam interaksi sosial, serta menimbulkan siswa menjadi bosan sehingga mengakibatkan rendahnya hasil belajar. Suatu pembaharuan dalam proses belajar mengajar dibutuhkan pada mata pelajaran kimia 
agar siswa dapat termotivasi untuk aktif selama pembelajaran sehingga hasil belajar siswa dapat meningkat. Salah satu langkah untuk membuat pembaharuan dalam proses belajar mengajar yaitu guru perlu menerapkan sebuah model pembelajaran yang sesuai dengan materi pelajaran yang diajarkan.

Pembelajaran cooperative (cooperative learning) adalah suatu model pembelajaran dimana siswa belajar dan bekerja dalam kelompok-kelompok kecil secara kolaboratif yang anggotanya 4 sampai 6 orang dengan struktur kelompok heterogen (Slavin, 1995). Pembelajaran kooperatif mengacu pada paham konstruktivisme, dimana siswa dituntut untuk belajar secara mandiri dan berkelompok, mengkontruksi pengetahuan, siswa diharuskan mengidentifikasi permasalahan yang ada, mencari penyelesaian, dan menyesuaikan hasil yang didapatkan dengan hasil yang benar. Keterampilan proses sains dapat ditingkatkan dengan melakukan perubahan atau variasi dalam model pembelajaran (Glason \& Lalik, 1993). Model pembelajaran yang sesuai dengan permasalahan yang telah di uraikan tersebut yaitu model pembelajaran yang berbasis konstruktivis. Teori pembelajaran konstruktivis merupakan teori pembelajaran kognitif yang baru dalam psikologi pendidikan yang menyatakan bahwa siswa harus menemukan sendiri dan mentransformasikan informasi kompleks, mengecek informasi baru dengan aturan-aturan lama dan merevisinya apabila aturan-aturan itu tidak sesuai lagi (Trianto, 2010). Salah satu model pembelajaran yang berbasis konstruktivis yang dapat di terapkan pada materi Hidrokarbon yaitu model pembelajaran kooperatif tipe Scramble (Rustam \& Adli, 2016). Pembelajaran dengan model pembelajaran kooperatif metode scramble, memiliki kesamaan dengan model pembelajaran kooperatif lainnya, yaitu siswa dikelompokkan secara acak berdasarkan kemampuan tinggi, sedang, dan rendah berbeda (Dahlan, 1984)

Hasil penelitian ini dimaksudkan untuk mendeskripsikan pengaruh penerapan model pembelajaran kooperatif tipe scramble terhadap hasil belajar siswa pada materi hidrokarbon di kelas X SMA Negeri 8 Palu.

\section{Metode}

Jenis penelitian yang digunakan yaitu penelitian eksperimen semu (quasi experimental research) yakni suatu jenis eksperimen yang pengendaliannya terhadap variabel tidak dilakukan begitu ketat atau secara penuh dan dengan pengontrolan yang sesuai dengan kondisi yang ada (situasional) (Sudjana \& Ibrahim, 2012).

\section{Populasi dan Sampel}

Populasi dalam penelitian ini adalah seluruh siswa kelas X SMA Negeri 8 Palu yang terdaftar pada tahun ajaran 2016-2017 yang berjumlah 84 orang siswa. Sampel dalam penelitian ini terdiri dari 55 orang siswa dari kelas XB dengan jumlah siswa 27 orang sebagai kelas eksperimen dan kelas XA dengan jumlah siswa 28 orang sebagai kelas kontrol. Pemilihan kelas yang menjadi sampel penelitian dilakukan melalui teknik purposive sampling (berdasarkan pertimbangan bahwa kedua kelas tersebut memiliki kesamaan pada kondisi ruangan yang digunakan untuk belajar, waktu pembelajaran dan prestasi belajar kimia yang hampir sama).

\section{Instrumen penelitian}

Instrumen yang digunakan pada penelitian ini adalah pilihan ganda yang berjumlah 20 soal disusun oleh peneliti dengan berpedoman pada Kurikulum Tingkat Satuan Pendidikan (KTSP) mata pelajaran kimia tahun 2006 dari pusat kurikulum. Soal tersebut digunakan untuk memperoleh data tes awal dan tes akhir siswa sehingga mendeskripsikan bagaimana pengaruh penerapan model pembelajaran kooperatif tipe Scramble terhadap hasil belajar siswa pada materi Hidrokarbon di kelas X SMA Negeri 8 Palu. Melalui tes ini diharapkan dapat mengungkapkan bagaimana penguasaan siswa pada pokok bahasan Hidrokarbon dalam rana kognitif. Data yang diperoleh diolah dengan menggunakan statistik parametrik dengan uji prasyarat data yang diperoleh harus berdistribusi normal dan bersifat homogen sebelum pengujian hipotesis dilakukan (Sudjana, 2002).

\section{Teknik Analisis Data}

Data pada penelitian dianalisis dengan menggunakan metode analisis dengan menggunakan uji $\mathrm{N}$-gain untuk mengetahui sejauh mana model pembelajaran yang diterapkan berpengaruh terhadap hasil belajar siswa. Dan analisis statistik inferensial (uji normalitas, homogenitas, dan Uji-t dua pihak) untuk menguji hipotesis kemudian menarik kesimpulan tentang perbedaan hasil belajar.

\section{Hasil Dan Pembahasan}

Perbandingan tes kemampuan awal dan akhir siswa kelas eksperimen dan kelas kontrol

Tes awal dilakukan dengan tujuan untuk mengetahui kemampuan awal siswa yang berada pada kelas eksperimen dan kelas kontrol sebelum pokok bahasan Hidrokarbon diajarkan kepada siswa. Sedangkan tes akhir siswa dilakukan dengan tujuan untuk mengetahui sejauh mana model pembelajaran yang diterapkan memberikan pengaruh terhadap hasil belajar kimia siswa. Deskripsi hasil pretest dan posttest siswa pada kelas eksperimen dan kelas kontrol dapat dilihat pada Tabel 1.

Hasil pretest pada Tabel 1 tersebut menunjukkan bahwa perbedaan nilai rata-rata siswa kelas eksperimen dan kelas kontrol relatif 
sama. Sedangkan hasil posttest menunjukkan bahwa nilai rata-rata siswa pada kelas eksperimen lebih tinggi daripada kelas kontrol, sehingga nilai rata-rata siswa yang diberi model pembelajaran kooperatif tipe scramble lebih tinggi daripada nilai rata-rata siswa yang diberi model pembelajaran konvensional. Pretest dan posttest pada penelitian ini dilakukan pada dua kelompok kelas, yaitu kelas $\mathrm{XB}$ yang berjumlah 27 orang sebagai kelas eksperimen dan kelas XA yang berjumlah 28 orang sebagai kelas kontrol. Pelaksanaan penelitian pada kelompok eksperimen dan kelompok kontrol menggunakan jumlah waktu pembelajaran yang sama, yaitu 6 jam pelajaran dengan pokok materi yang disampaikan juga sama yaitu hidrokarbon, tetapi perlakuan yang berbeda dilakukan pada model pembelajaran yang digunakan, di mana kelompok eksperimen menggunakan model pembelajaran kooperatif tipe scramble sedangkan kelompok kontrol menggunakan model pembelajaran konvensional. Soal yang diujikan sebanyak 20 butir soal yang terlebih dahulu dilakukan validasi isi dan validasi instrument (Arikunto, 2006).

Tabel 1. Data pretest dan posttest hasil belajar siswa

\begin{tabular}{|c|c|c|c|c|}
\hline \multirow{3}{*}{ Uraian } & \multicolumn{2}{|c|}{ Tes awal (pretest) } & \multicolumn{2}{|c|}{ Tes akhir (posttest) } \\
\hline & Kelas & Kelas & Kelas & Kelas \\
\hline & Eksperimen & Kontrol & Eksperimen & Kontrol \\
\hline \multirow{2}{*}{$\begin{array}{l}\text { Sampel } \\
\text { Nilaiterendah }\end{array}$} & 27 & 28 & 27 & 28 \\
\hline & 0 & 0 & 50 & 45 \\
\hline Nilaitertinggi & 35 & 30 & 90 & 85 \\
\hline Nilairata-rata & 18,14 & 20,17 & 72,44 & 67 \\
\hline
\end{tabular}

\section{Hasil Analisis Data N-Gain}

Pengujian $<\mathrm{g}>$ dilakukan untuk menganalisis data dengan cara mendeskripsikan atau menggambarkan data yang telah terkumpul berdasarkan pencapaian masing-masing variabel dalam hubungan nilai pretes dan postes siswa pada kelas eksperimen maupun kelas kontrol. Berikut ini grafik hubungan nilai pretest dan posttest siswa pada kelas eksperimen dan kelas kontrol dapat dilihat pada Gambar 1.

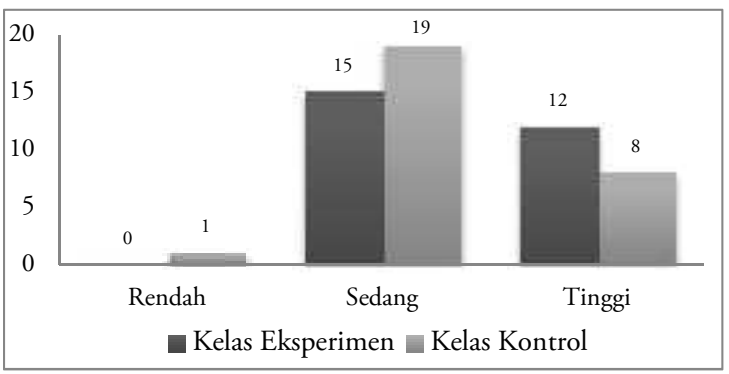

Gambar 1. Nilai N-gain kelas kelas eksperimen dan kontrol

Berdasarkan Gambar 1 di atas, maka perbedaan peningkatan tes hasil belajar siswa kelas eksperimen dan kelas kontrol cukup signifikan. Siswa kelas eksperimen lebih banyak mendapat kategoritinggi dari pada siswa kelas kontrol, yaituhasil uji $\mathrm{N}$-gain yang diperolehdari kelas eksperimen yaitu kategori sedang 15 orang dan kategori tinggi 12 orang, Sedangkan hasil dari kelas kontrol yaitu kategori rendah 1 orang, kategori sedang 19 orang dan kategori tinggi 8 orang. Hal ini disebabkan pada saat proses pembelajaran berlangsung, siswa yang menggunakan model pembelajaran kooperatif tipe scramble memiliki waktu yang relatif lebih banyak untuk berinteraksi dengan siswa lain berbagi ide dan solusi terhadap masalah yang diberi.Berbeda dengan siswa yang diajar denganmodel pembelajaran konvensional, siswa hanya monoton ditempat saja tanpa harus berinteraksi dengan siswa lain yang memiliki kemampuan lebih, dimana ketika siswa yang berkemampuan rendah duduk sebangku maka akan menyusahkan siswa tersebut untuk memecahkan dan menemukan solusi dari masalah yang diberi, karena tidak ada berinteraksi dengan siswa lain yang berkemampuan lebih tinggi.

\section{Hasil Analisis Inferensial}

Pengujian hipotesis pada penelitian ini menggunakan uji-t dua pihak baik kelas eksperimen maupun kelas kontrol memiliki data yang berdistribusi normal berturut-turut: $\chi_{\text {hitung }}^{2}<\chi_{\text {tabel }}^{2}$ yaitu $7,02<7,81$ dan $\chi_{\text {hitung }}^{2} \chi^{2}$ tabel yaitu $5,72<7,81$, juga varians yang homogen dengan nilai $\mathrm{F}_{\text {hitung }}<\mathrm{F}_{\text {tabel }}$ yaitu $1,014<1,93$, serta analisis uji $\mathrm{t}$-dua pihak diperoleh $-\mathrm{t}_{\text {tabel }}<\mathrm{t}_{\text {hitung }}>+\mathrm{t}_{\text {tabel }}\left(\mathrm{t}_{\text {hitung }}\right.$ $=2,37$ dan $\left.t_{\text {tabel }}=1,67\right)$ jelas berada pada daerah penolakan $\mathrm{H}_{0}$ sehingga $\mathrm{H}_{0}$ ditolak dan $\mathrm{H}_{a}$ diterima, maka dapat dikatakan bahwa ada pengaruh model pembelajaran kooperatif tipe scramble terhadap hasil belajar siswa.

Berdasarkan data yang diperoleh baik pada uji analisis data $N$-gain maupun statistik inferensial model pembelajaran kooperatif tipe scramble memiliki pengaruh pada hasil belajar siswa, hasil tersebut akibat dari kelebihan kooperatif tipe scramble yakni siswa merasa bertanggung jawab atas soal yang diberikan dalam setiap kelompoknya, dimana dalam satu kelompok terdiri dari 4 sampai 6 orang, diberikan lembar kerja serta lembar jawaban yang jawaban tiap nomorya diacak berdasarkan abjadnya, soal yang diberikan harus diselesaikan secara berkelompok (Momitha, 2012). Siswa sengaja diberikan lembar kerja dan lembar jawaban yang sedemikian unik, sehingga siswa tidak merasa jenuh dan lebih giat belajar pada saat proses pembelajaran berlangsung. Pola pembelajaran dengan model pembelajaran kooperatif tipe scramble mengarahkan siswa tentang bagaimana mereka belajar secara individu dan belajar secara bersama-sama dalam suatu kelompok belajar, melibatkan diri dalam proses belajar serta berdiskusi dalam kelompoknya untuk meyelesaikan soal-soal yang diberikan karena inilah implikasi dari pembelajaran kooperatif yaitu metode pembelajaran di mana guru mengatur 
siswa ke dalam kelompok-kelompok kecil (Tran, 2014). Hal ini sejalan dengan pendapat bahwa pengajaran yang efektif menghendaki guru memfasilitasi siswa belajar dengan diskusi agar siswa bisa belajar bekerja sama dan bisa belajar aktif untuk melatih keberanian dan kepercayaan diri siswa dalam proses pembelajaran dikelas (Prawoto, 2012).

Pembelajaran scramble membuat siswa dapat lebih berinteraksi satu dengan yang lain dalam keompoknya untuk menyelesaikan soal dengan jawaban acak yang tersedia sehingga pembelajaran lebih menyenangkan dan siswa menjadi semangat dalam belajar (Elisa, 2014). Terlihat pada tes awal dan tes akhir siswa yang menunjukkan peningkatan yang lebih tinggi pada kelas yang diberikan model pembelajaran kooperatif tipe scramble, serta hasil pengujian hipotesis yang menunjukkan bahwaada pengaruh model pembelajaran kooperatif tipe scramble terhadap hasil belajar siswa, maka dapat dikatakan bahwa model pembelajaran kooperatif tipe scramble memberi pengaruh positif terhadap hasil belajar siswa kelas X SMA Negeri 8 Palu.

Rendahnya hasil belajar siswa pada kelas yang menggunakan model pembelajaran konvensional di karenakan dalam proses pembelajaran siswa hanya mendengarkan dan mencatat apa yang disampaikan oleh guru. Ketika diberi suatu masalah, jawaban dicari oleh masing-masing individu tanpa harus berbagi ide dengan individu lain yang memiliki kemampuan lebih yang berbeda-beda. Sehingga siswa yang berkemampuan rendah ketika diberi suatu masalah yang agak sulit akan terlihat kurang aktif karena tidak tahu bahkan timbul rasa malas untuk memecahkan masalah tersebut.

Penerapan model pembelajaran kooperatif tipe scramble dalam penelitian ini memiliki beberapa kendala pada pelaksanaannya. Kendala yang biasa ditemukan yaitu siswa belum terlalu memahami dan terbiasa untuk belajar dengan menggunakan model pembelajaran kooperatif tipe scramble yang diterapkan peneliti pada proses pembelajaran sehingga siswa agak sulit untuk menyesuaikan diri dan durasi waktu yang digunakan pada proses pembelajaran cukup memakan waktu yang lama sehingga guru harus memiliki managemen waktu yang baik untuk menerapkan model pembelajaran ini.

\section{Kesimpulan}

Penerapan model pembelajaran kooperatif tipe scrambleberpengaruh terhadap hasil belajar siswa pada materi hidrokarbon kelas X SMA Negeri 8 Palu, skor rata-rata postest masing-masing kelas, yaitu siswa kelas eksperimen $=72,4$ dan siswa kelas kontrol $=67$. Pengujian hipotesis dengan menggunakan uji t-dua pihak dengan kriteria pengujiannya adalah jika $-\mathrm{t}_{\text {tabel }} \leq \mathrm{t}$ hitung $\leq+\mathrm{t}_{\text {tabel }}$ maka $\mathrm{H}_{0}$ diterima dan $\mathrm{Ha}$ ditolak dengan $\mathrm{dk}=\left(\mathrm{n}_{1}\right.$ $+\mathrm{n}_{2}-2$ ) dan taraf signifikansi $\alpha=0,05$, diperoleh $-\mathrm{t}_{\text {tabel }}<\mathrm{t}_{\text {hitung }}>+\mathrm{t}_{\text {tabel }}(-1,67<2,37>+1,67)$ dengan taraf signifikansi $\alpha=0,05$ dan derajat kebebasan 53 , nilai ini berada pada daerah penolakan $\mathrm{H}_{0}$ maka $\mathrm{H}_{\mathrm{a}}$ diterima.

\section{Ucapan Terimakasih}

Penulis mengucapkan terimakasih kepada Drs. Salim, MM Kepala sekolah Azwar, S.Pd Guru Kimia dan siswa kelas XA dan XB SMA Negeri 8 Palu Tahun Ajaran 2015-2016.

\section{Referensi}

Arikunto, S. (2006). Dasar-dasar evaluasi pendidikan. Jakarta: Bina Aksara.

Dahlan. (1984). Model-model mengajar. Bandung: CV.Diponegoro.

Elisa. (2014). An analysis of the second year students' ability of SMAN 1 suliki in rearranging scrambled sentences into a good hortatory exposition text. $e$ - jurnal Bunghatta, 3(5), 1-8.

Glason, G. E. \& Lalik, R. V. (1993). Reinterpeting the learning cycle from social contructivist prespective: A qualitative study of teachers beliefs and practices. Journal of Research in Science Teaching, 30(2), 187-207.

Gustiana, M. (2012). Penerapan Kolaborasi Model Pembelajaran Scramble Dengan Course Review Horay Untuk Meningkatkan Aktivitas Dan Hasil Belajar Akuntansi Siswa Kelas Xii Ips 4 Sma Negeri 1 Pematangsiantar Tahun Ajaran 2012/2013. Skripsi Pendidikan Akuntansi Medan: Universitas Negeri Medan. Tidak Diterbitkan.

Momitha, D. (2012). Pengaruh model pembelajaran kooperatif tipe scramble terhadap hasil belajar siswa kelas viii smp negeri 3 banawa. Skripsi Sarjana. Palu: Program Studi Pendidikan Fisika FKIP UNTAD. Tidak Diterbitkan.

Nasution, A. (2014). Perbedaan media handout dan media scramble dengan model pembelajaran discovery learning terhadap peningkatan hasil belajar siswa pada materi sistem koloid. Skripsi Pendidikan Kimia Universitas Negeri Medan. Tidak Diterbitkan.

Prawoto, A. (2012). Pembelajran dengan pendekatan based brain learning untuk meningkatkan hasil belajar matematika. Thesis. Bandung: Pascasarjana UPI. Tidak diterbitkan.

Purba, M. (2006). Kimia untuk SMA/MA kelas X. Jakarta: Penerbit Erlangga.

Rustam, A. \& Adli, M. (2016). Improving the results of math learning through scramble cooperative model with the approach of contextual teaching and learning model. Journal of Mathematics Education, 1(1), 7-14.

Slavin, R. E. (1995). Cooperative learning, second edition. Boston: Allyn and Bacon. 
Sudjana, N. (2002). Penilaian proses hasil belajar mengajar. Bandung: Remaja Rosdakarya.

Sudjana, N. \& Ibrahim. (2012). Penelitian dan penilaian pendidikan. Bandung: Sinar Baru Algensindo.

Tran, V. D. (2014). The effects of cooperative learning on the academic achievement and knowledge retention. International Journal of Higher Education, 3(2), 131-140.

Trianto. (2010). Mendesain model pembelajaran inovatif-progresiv. Jakarta: Kencana Prenada Media Group. 